\title{
Endokrin szövődmények primer immundeficientiában
}

\author{
Halász Zita dr. \\ Semmelweis Egyetem, Általános Orvostudományi Kar, I. Gyermekgyógyászati Klinika, Budapest
}

\begin{abstract}
Az immun- és endokrin rendszer közötti szoros kapcsolatot számos kísérleti és klinikai adat igazolja. Alig rendelkezünk azonban olyan átfogó epidemiológiai vizsgálat eredményével, mely az endokrinológiai szövődmények megjelenését vizsgálja primer immundeficientiában. Az immundeficientia-szindróma és az autoimmun megbetegedések kialakulása közötti szoros kapcsolat jól ismert. Az endokrin rendszer eltéréseit a leggyakrabban az immundiszreguláció és az autoimmunitás folyamata okozza, így APECED- (autoimmun polyendocrinopathia, candidiasis, ectodermalis dystrophia) és IPEX- (immundiszreguláció, polyendocrinopathia, enteropathia, X-hez kötött) szindrómában is. Ezen kórképekben az autoreaktív T-sejtek által mediált immunológiai destruktív folyamat idézi elő a hormontermelő szervek többszörös károsodását, így a pajzsmirigy-, mellékpajzsmirigy-, mellékvesekéreg- és endogénhasnyálmirigy-elégtelenséget. A primer immundeficientia egyes formáiban, például a Di George-szindrómában is, az endokrin szervek érintettségét elsődlegesen a kórkép hátterében igazolt genetikai eltérés okozza, az autoimmun folyamat szerepe azonban itt is igazolt. A szerző áttekinti a primer immundeficientiához társuló endokrinológiai szövődményeket és a lehetséges patomechanizmust APECED-, IPEX-szindrómában, Di George-szindrómában és ataxia teleangiectasiában.

Orv Hetil. 2018; 159(49): 2065-2072.
\end{abstract}

Kulcsszavak: primer immundeficientia, endokrin szövődmény, APECED-szindróma, IPEX-szindróma, Di Georgeszindróma

\section{Endocrine complications in primary immunodeficiency diseases}

Experimental and clinical data suggest a complex interaction between the endocrine and immune systems. However, only few epidemiological studies are available dealing with endocrine complications in different types of primary immunodeficiency diseases. It is well documented that there is a close association between immunodeficiency syndromes and the development of autoimmune disorders. Most of the endocrine dysfunctions are caused mainly by immune dysregulation and autoimmunity like in APECED (autoimmune polyendocrinopathy, candidiasis, ectodermal dystrophy) and IPEX (immune dysregulation, polyendocrinopathy, enteropathy, X-linked) syndromes. In these disorders, an immunologically mediated destructive process by autoreactive $\mathrm{T}$ cells damages multiple endocrine organs like the thyroid, parathyroid, adrenal cortex and endocrine pancreas. In some other forms of immunodeficiencies, like Di George syndrome, endocrine disturbances are mainly caused by the underlying genetic disorders but autoimmunity may also take part in the process. The aim of this paper is to give an overview of the different forms of endocrine disturbances and their pathological background in APECED and IPEX syndromes, Di George syndrome and ataxia telangiectasia.

Keywords: primary immunodeficiency disease, endocrine complication, APECED syndrome, IPEX syndrome, Di George syndrome

Halász Z. [Endocrine complications in primary immunodeficiency diseases]. Orv Hetil. 2018; 159(49): $2065-2072$.

(Beérkezett: 2018. március 10.; elfogadva: 2018. április 21.)

\section{Rövidítések}

ACTH = adrenokortikotrop hormon; AIRE-gén = (autoimmune regulator gene) autoimmun szabályozógén; APECED = autoimmun polyendocrinopathia, candidiasis, ectodermalis dystrophia; APSI = (autoimmune polyendocrine syndrome type 1) autoimmun poliendokrin szindróma 1-es típusa; CaSR $=($ calcium-sensing receptor $)$ kalciumérzékelő receptor; $\mathrm{CRH}=$ (corticotropin-releasing hormone) kortikotropinfelszabadító hormon; CYP450c17 = 17 $\alpha$-hidroxiláz / 17,20-liáz; CYP450c21 = 21-hidroxiláz; CYP450scc $=($ cholesterol side-chain claevage 
enzyme - 20,22-desmolase) koleszterinoldallánc-hasító enzim - 20,22-dezmoláz; FOXP3 = forkhead box P3; FSH = folliculusstimuláló hormon; GAD65 = (glutamic acid decarboxylase 65 isoform) glutaminsav-dekarboxiláz 65-ös izoformája; GAD67 = (glutamic acid decarboxylase 67 isoform $)$ glutaminsav-dekarboxiláz 67-es izoformája; GH = (growth hormone) növekedési hormon; IAA = (insulin autoantibody) inzulin-autoantitest; IA2 $=($ tyrosine phosphatase-related islet antigen- 2$)$ tirozin-foszfatáz elleni antitest; ICA = (islet cell antibody) szigetsejtellenes antitest; IFN $\alpha=$ interferon- $\alpha$; IGF1 $=$ (insulinlike growth factor 1 ) inzulinszerü növekedési faktor-1; IPEX = immundiszreguláció, polyendocrinopathia, enteropathia, Xhez kötött; LH = (luteinizing hormone) luteinizálóhormon; $\mathrm{NF}-\mathrm{KB} 2=$ (nuclear factor kappa B subunit 2; nukleáris faktorkappa-B 2-es alegysége; NLRP5 = (NOD-like receptor family pyrin domain containing 5 ) NOD-szerű receptorcsalád pyrin domént hordozó fehérje-5; PID = (primary immunodeficiency disease) primer immundeficientia; $\mathrm{pl}=$ plazma; $\mathrm{PRA}=$ plazmarenin-aktivitás; se = szérum; $\mathrm{T} 1 \mathrm{DM}=($ type 1 diabetes mellitus) 1-es típusú cukorbetegség; T2DM = (type 2 diabetes mellitus) 2-es típusú cukorbetegség; TBXI = T-box-1-gén; TDRD6 = (tudor domain containing protein 6$)$ tudor domént tartalmazó fehérje-6; Tg = thyreoglobulin; TGM4 = transzglutamináz-4; TPO = thyreoidea-peroxidáz; ZNT8 = $($ zinc transporter 8) cinktranszporter-8

Az immun- és az endokrin rendszer szoros kapcsolatát számos ismert élettani és patológiai folyamat bizonyítja, ma már neuro-endokrin-immun rendszerről beszélünk. A rendszeren belül a jelátvitelt a hormonok, a neurotranszmitterek és a citokinek biztosítják. Erre a kölcsönös viszonyra példa a citokinek hatása a hypothalamohypophysealis-mellékvese tengely aktivitásában vagy hormonhatások igazolása a lymphocytákon expresszálódó receptorokon keresztül, például noradrenalin, szerotonin, szexszteroid, CRH- (corticotropin-releasing hormone) hatás [1-4]. A primer immundeficientiák (PID) legtöbb formájában a klinikai adatok az endokrinológiai diszfunkciók prevalenciájának megnövekedését támasztják alá. A hormonháztartás zavaráért jelentős részben a primer immundeficientiában gyakran kialakuló, az autoreaktív T-sejtek által közvetített, az endokrin szerveket is érintő destruktív folyamat tehető felelőssé $[5,6]$. Egyes esetekben a PID-et kiváltó genetikai eltérés a hormontermelő szerv/szervek zavarát közvetlenül idézi elő. A PID klinikai megjelenését a kórképasszociált endokrinológiai diszfunkciók jelentősen tarkítják, és kórlefolyását súlyosbítják.

\section{Epidemiológiai vizsgálatok PID-ben}

A PID-del járó kórképek közül az APECED- (autoimmun polyendocrinopathia, candidiasis, ectodermalis dystrophia), az IPEX- (immundiszreguláció, polyendocrinopathia, enteropathia, X-hez kötött) és a Di Georgeszindróma vonatkozásában a kórképasszociált endokrinológiai eltéréseket széles körben vizsgálták. Azonban egyedül Japánban készült olyan átfogó epidemiológiai vizsgálat, mely a PID-ben előforduló hormonális eltéréseket dolgozta fel országos felmérés keretében $[7,8]$. Nozaki és mtsai 923, PID-ben szenvedő beteg klinikai adatait dolgozták fel. A betegek 5,3\%-ában diagnosztizáltak endokrinológiai megbetegedést. A fiatal korosztályban (<19 év) az endokrinológiai eltérések prevalenciája az átlaghoz képest kiugróan magas volt $(232,6 / 10000$ és 0,072/10 000). Ezen prevalenciaemelkedés az autoimmun diszregulációban szenvedő betegek adatai nélkül is megfigyelhető volt. A PID egyes formáihoz társuló endokrinológiai eltéréseket az 1. táblázat tartalmazza. A leggyakoribb endokrinológiai diszfunkciónak a Di George-szindróma részeként előforduló hypoparathyre-

1. táblázat | Endokrinológiai diszfunkciók előfordulása PID-ben [5]

\section{Kombinált T-és B-sejt-defektus}

RAGl-deficientia/nem autoimmun hypothyreosis

CD4-deficientia/autoimmun hypothyreosis

Nem meghatározott kórkép/nem autoimmun hypothyreosis, GHD Elsödleges antitesthiány

$\mathrm{X}$-hez kötött agammaglobulinaemia/nem autoimmun hypothyreosis

Variábilis immundeficientia/T1DM, autoimmun hypothyreosis, GHD, ACTH-hiány, IgG-alosztály-deficientia/nem autoimmun hypothyreosis

Nem meghatározott/T1DM, GHD, hypogonadismus

Egyéb jól differenciált immunhiány-szindróma

Hiper-IgE-szindróma/GHD, hypogonadismus

Di George-szindróma/hypoparathyreosis

Ataxia teleangiectasia/T2DM

Krónikus mucocutan candidiasis/autoimmun hypothyreosis

ICF-szindróma/hypogonadismus

Az immunreguláció zavara

IPEX-szindróma/T1DM, autoimmun hypothyreosis

APECED-szindróma/hypoparathyreosis

Nem osztályozott/T1DM, autoimmun hypothyreosis

A phagocytosis veleszületett zavarai

Krónikus granulomatosis/nem autoimmun hypothyreosis, GHD

Shwachman-Diamond-szindróma/GHD

\section{A veleszületett immunitás zavara}

NEMO-deficientia/hypophosphataemiás rachitis

WHIM-szindróma/nem autoimmun hypothyreosis, TIDM

Autoinflammatiós kórképek

Familiáris mediterrán láz/T2DM

ACTH $=$ adrenokortikotrop hormon; APECED = autoimmun polyendocrinopathia, candidiasis, ectodermalis dystrophia; GHD = növekedésihormon-hiány; ICF = immundeficientia, arc környéki torzulások; IgG = immunoglobulin-G; IPEX = immune dysregulation, polyendocrinopathy, enteropathy, X-linked; NEMO = nuclear factor kappa-B essential modulator; PID = primer immundeficientia; $\mathrm{T} 1 \mathrm{DM}=1$-es típusú diabetes mellitus; T2DM = 2-es típusú diabetes mellitus; WHIM $=$ (warts, hypogammaglobulinemia, infections, myelokathexis) szemölcsök, hypogammaglobulinaemia, infekciók, myelocathexis 
osis adódott, ugyanakkor a vizsgált beteganyagban Graves-Basedow-kór nem fordult elő. A japán populáció sajátosságának tekinthető, hogy a feldolgozott anyagban mellékvesekéreg-elégtelenséget nem észleltek, továbbá az irodalmi adatokhoz képest az autoimmun thyreoiditis IPEX-szindrómában ritkább volt.

\section{Endokrinológiai eltérések az immunreguláció primer defektusaiban}

\section{APECED- (autoimmun polyendocrinopathia, candidiasis, ectodermalis dystrophia) szindróma}

Az APECED-, más néven APS1- (autoimmune polyendocrine syndrome type 1 ; autoimmun poliendokrin szindróma l-es típusa) szindróma monogénes, autoszomális recesszíven öröklődő ritka megbetegedés. A kórkép kialakulásáért felelős $A I R E$-gén (autoimmune regulator gene) mutációja a centrális immuntolerancia diszregulációját okozza. Az utóbbi években ismertté vált úgynevezett inkomplett APSl-szindróma az AIRE-gén heterozigóta domináns negatív mutációjának következménye, melyben a tünetek későbbi életkorban, enyhébb formában manifesztálódnak [9, 10]. Feltételezhető, hogy egyes izolált szervspecifikus autoimmun folyamatok hátterében inkomplett APS1-szindróma áll.

Az APECED-szindróma ritka betegség. Gyakorisága az iráni zsidó, finn és szardíniai populációban 1 : 90001 : 25 000, a nyugat-európai populációban $1: 200000$. A megbetegedettek között a nő : férfi arány 0,8-2,4.

Az APECED („klasszikus” APSl-szindróma) primer immundefektust és szövetspecifikus autoimmunitást egyaránt okoz. Három fó klinikai tünete közül (mucocutan candidiasis, hypoparathyreosis, primer hypadrenia) a két fó tünet az endokrin szervek elleni autoimmunitás, a mellékvese és mellékpajzsmirigy destrukciójához vezető folyamat következménye [11].

APECED-szindróma esetén az endokrinológiai szervek érintettségének gyakorisága között jelentős földrajzi, illetve populációs eltérés van. Míg Európában az endokrinológiai manifesztációk gyakoribbak (például APECED-ben szenvedő finn betegekben a TIDM a többi populációs előforduláshoz képest kiemelkedően gyakori), Ferre amerikai populációban végzett vizsgálatai a szindrómában a nem endokrin manifesztációk (például urticariaszerű erupció, hepatitis, gastritis, intestinalis diszfunkció, pneumonitis, Sjögren-szerű kórkép) gyakori megjelenését igazolta [12-15]. Ugyanezen beteganyagban az urticariaszerü erupciók, az intestinalis diszfunkciók és a körömhypoplasia sok esetben a kórkép korai manifesztációi voltak [15].

Az endokrin szervek részéról antitestképződést kiváltó antigének és a kialakuló kórképek felsorolását a 2. táblázat tartalmazza. A leggyakoribb a mellékpajzsmirigy és a mellékvesekéreg ellen termelődő ellenanyag képződése,
2. táblázat $\mid$ Endokrin célszervek, antigének és az autoimmun folyamat klinikai megjelenései APECED-szindrómában

\begin{tabular}{lll}
\hline Célszerv & Antigén & Kórkép \\
\hline Agyalapi mirigy & GH & Hypopituitarismus \\
& TDRD6 & ? \\
\hline Hasnyálmirigy & GAD65, IA2, GAD67, & T1DM \\
& IAA, ICA, ZNT8 & \\
\hline $\begin{array}{l}\text { Mellékpajzs- } \\
\text { mirigy }\end{array}$ & NLRP5, CaSR & $\begin{array}{l}\text { Primer hypoparathyreo- } \\
\text { sis }\end{array}$ \\
\hline Mellékvese & CYP450C21, & Addison-kór \\
& CYP450c17, & \\
& CYP450scc & (?) \\
\hline Here & CYP450C21, & Primer hypogonadismus \\
& CYP450c17, & \\
CYP450scc & TDRD6 & A spermiumképzés \\
Petefészek & CYP450scc & zavara (?) \\
& & Primer hypogonadismus \\
\hline Pajzsmirigy & Thyreoglobulin & Primer hypothyreosis \\
& Thyreoidea peroxidáz & \\
\hline Prosztata & TGM4 & Infertilitás \\
\hline
\end{tabular}

APECED = autoimmun polyendocrinopathia, candidiasis, ectodermalis dystrophia; CaSR = kalciumérzékelő receptor; $\mathrm{CYP} 450 \mathrm{cl}=$ 17 $\alpha$-hidroxiláz / 17,20-liáz; CYP450c21 = 21-hidroxiláz; CYP450scc = koleszterinoldallánc-hasító enzim - 20,22-dezmoláz; GAD65 = glutaminsav-dekarboxiláz 65-ös izoformája; GAD67 = glutaminsav-dekarboxiláz 67-es izoformája; GH = növekedési hormon; IA2 = tyrosine phosphatase-related islet antigen-2; IAA = inzulin-autoantitest; ICA = szigetsejtellenes antitest; NLRP5 = NLR family pyrin domain containing $5 ;$ T1DM = 1 -es típusú diabetes mellitus; TDRD6 = tudor domain containing protein 6 ; TGM4 = transzglutamináz-4; ZNT8 = cinktranszporter- 8

mely az élet során a betegek több mint $80 \%$-ában megjelenik [12-14, 16-18].

A kórképre jellemző első klinikai jel általában gyermekkorban jelentkezik, de manifesztálódhat néhány hónapos kortól a felnőttkorig bármikor. Az anticitokinautoantitestek (interferon-omega-, interferon- $\alpha 2$-, interleukin-22-autoantitest) megjelenése megelőzheti az APECED klinikai tüneteit [19]. A leggyakrabban a csecsemőkor után megjelenő, változó súlyosságú candidiasis manifesztálódik; a patogenezisben szerepet játszik az interleukin-17A-, interleukin-17F- és interleukin-22-autoantitestek megjelenése [20]. A mucocutan candidiasist a késóbbiekben a primer hypoparathyreosis és a primer hypadrenia követi. A hypoparathyreosis általában már az első évtizedben manifesztálódik (a leggyakrabban 2 és 4 év között), de a csecsemókortól a felnőttkorig bármelyik életkorban megnyilvánulhat. Gyakorisága változó: finn populáció 20\%-ában mint egyetlen endokrinológiai diszfunkció jelentkezett, amerikai populációra vonatkozó felmérés szerint azonban a hypoparathyreosis volt a leggyakoribb, sok esetben az egyetlen endokrinológiai eltérés [12-15].

Primer hypoparathyreosisban az egyik mellékpajzsmirigy-specifikus antigén a citoplazmában elhelyezkedő 
NLRP5- (NLR family pyrin domain containing 5) receptor, melynek élettani feladata nem ismert. Az antitest egészséges kontrollok körülbelül 3\%-ában kimutatható. Kempés mtsai adatai szerint az APECED-es betegek esetében a hypoparathyreosis manifesztációja nélkül az antitest nem jelenik meg, azonban a hypoparathyreosisban szenvedő betegek közel felében az NLRP5 antigén elleni autoantitest kimutatható [21]. A másik autoantitest, a CaSR- (calcium-sensing receptor) ellenes antitest a finn APECED-betegek 40\%-ában volt igazolható. Az az elképzelés azonban, hogy az NLRP5- és a CaSR-antitest az APECED-ben a hypoparathyreosis kialakulásának szenzitív és specifikus markere, még napjainkban is vitatott [21].

A primer hypadrenia rendszerint a hypoparathyreosis kialakulását követi, típusosan 10-14 éves életkorban. Klinikai tünetei az étvágytalanság, fogyás, adynamia, hypotonia, hiperpigmentáció elsődlegesen a szájnyálkahártyán és a tenyéri redőkben, de diffúz hiperpigmentáció megjelenése sem ritka. Általános laboratóriumi jelei a hypoglykaemia, a hyponatraemia, a hyperkalaemia és az acidosis. A mellékvesekéreg-ellenes antitestek megjelenése általában évekkel megelőzi a hypadrenia kialakulását. A mellékvesekéreg esetében az autoimmun folyamatban a szteroidbioszintézis egyes enzimei mint autoantigének játszanak szerepet. A leggyakoribb a CYP450c21 (21-hidroxiláz), de gyakran észlelhető CYP450c17 (17 $\alpha$-hidroxiláz) és CYP450scc (cholesterol side-chain cleavage desmolase) antigén elleni autoantitest is. A hypoparathyreosis esetén gyakran kimutatható NLRP5-autoantitest megjelenése eddig nem ismert patomechanizmussal a mellékvesekéreg-elégtelenség kialakulásával is összefüggést mutat $[17,22-24]$.

A mellékvesekéreg-elégtelenség klinikai tünetei mellett a szteroidbioszintézisben szerepet játszó enzimek elleni autoimmunitási folyamat gonadinsufficientiát is előidézhet. CYP450scc-antitest primer ovarialis károsodást, CYP450scc-, CYP450c21- és CYP450c17-autoantitest megjelenése testicularis károsodást okoz. Állatkísérletes adatok szerint az APECED kialakulásához vezető $A I R E$-gén-mutációk a gonaddiszfunkció mellett a decidua kialakulását és az embrió megtapadási folyamatát is megzavarják [17].

APECED-es betegekben az l-es típusú diabetes mellitus gyakorisága 1-18\%, manifesztációja a finn populációban a legnagyobb. Általában jelentősen emelkedett antitestszinttel jár, döntően erôs GAD65- (glutamic acid decarboxylase 65 isoform) és IA2- (tyrosine phosphatase-related islet antigen-2) pozitivitás jellemzi. ICA(islet cell antibody), IAA- (insulin autoantibody) és GAD67- (glutamic acid decarboxylase 67 isoform) antitest megjelenése ritka. A kórképben a megjelenő antiIFN $\alpha$-antitest típusa a diabetes mellitus kialakulását jellemzi. Emelkedett nem neutralizáló anti-IFN $\alpha$ antitest-szint-emelkedés a diabetes mellitusszal, míg emelkedett neutralizáló anti-IFN $\alpha$-antitest-szint a diabe- tes mellitusszal nem szövődött APECED-es betegekben igazolható $[25,26]$.

A pajzsmirigy-érintettség Európában 2-11\%, amerikai vizsgálati adatok azonban gyakoribb pajzsmirigy-diszfunkciót jeleznek $[11,15,16]$. Egyes AIRE-gén-mutációk a pajzsmirigyellenes antitestek (antithyreoidea-peroxidáz- és antithyreoglobulin-antitest) képződésére fokozott hajlamot jelentenek.

A TDRD6- (tudor domain containing protein 6) hypophysisantigén-ellenes antitest jelenlétét igazolták az APECED-es betegek felében, de az antitestszint az agyalapimirigy-funkció csökkenésével nem korrelál. Azon ritka esetekben, amikor hypopituitarismus kialakult, többnyire gyermekkorban kezdődő izolált növekedésihormon-hiány manifesztálódott. A pituitaer enoláz és más citoszol protein ellen termelődő ellenanyag megjelenése a hypophysissejt-destrukciót követő, másodlagos folyamatnak tekinthető [27].

\section{IPEX-(immundiszreguláció, polyendocrinopathia, enteropathia, $X$-hez kötött) szindróma}

X-hez kötött, jelentős klinikai heterogenitást mutató genetikai megbetegedés. Zavartalan intrauterin fejlődést és postnatalis adaptációt követően a klinikai tünetek általában néhány hónapos korban jelentkeznek (pár napos életkorban manifesztálódó megbetegedésforma is előfordul). A TIDM az IPEX-szindróma >60\%-ában kialakul, tünetei már 1 hónapos korban megjelenhetnek. Permanens neonatalis diabetes mellitusban szenvedő fiúk 4\%-ában IPEX- szindrómát igazoltak [25]. Egyes esetekben azonban már az autoimmun folyamat intrauterin kezdetére utal a leírt magzati pancreashypoplasia és -hypotrophia [28]. Postnatalisan a szövettani képet pancreasdestrukció és lymphocytás beszűrődés jellemzi. A kórképre az enteropathia 100\%-os megjelenése jellemző, a súlyos hasmenés és bacterialis infekciók 1-2 éves korban gyakran halálhoz vezetnek. A diabetes mellitus a diarrhoeát megelőzheti, de követheti is. A kórképet nehezen kezelhető, IAA-, ICA- és GAD-autoantitest megjelenésével kísért TIDM jellemzi. Autoantitest megjelenése nélküli diabetes mellitus is előfordul.

A thyreoiditis általában a betegek egyharmadában jelentkezik, mely többnyire a pajzsmirigy hipofunkciójához vezet, hyperthyreosist ritkábban okoz. Antithyreoglobulin- és antiperoxidáz-antitest euthyreoticus stádiumban is jelen lehet [6].

A kórképre a klinikai heterogenitás jellemző. Barzaghi és mtsai egy 15 éves fiú esetét ismertették, akiben a neonatalis diabetes mellitus és a későbbiekben kialakuló nephrosisszindróma volt az IPEX-szindróma egyedüli klinikai manifesztációja [29]. A FOXP3-gén-mutáció lokalizációjától és a gén expresszióját befolyásoló számos ismert epigenetikai faktortól (például CpG „residues” metilációjától) függően atípusos, későn manifesztálódó 
úgynevezett late onset (késői kezdetû) IPEX-forma is ismert.

A 2017-ben publikált, internacionális multicentrikus respektív vizsgálat a kórkép manifesztációjának és a betegség progressziójának elemzését, továbbá a rendelkezésre álló terápiás lehetőségek értékelését tüzte ki célul [30]. A tanulmányban 96, genetikailag igazolt (betegségokozó FOXP3-gén; forkhead box P3 defektus kimutatásán alapuló) IPEX-szindrómás beteg adatainak öszszesítésére került sor. A betegség manifesztációjakor az átlagos életkor 2 hónap volt (megszületéstől 11,3 éves korig). Az első tünet és a diagnózis felállítása között átlagosan 14 hónap telt el. A neonatalis forma a jellegzetes triáddal manifesztálódott (ekcéma, gastrointestinalis tünet és T1DM). Egy hónapos életkor után az ekcéma és a gastrointestinalis tünet volt jellegzetes, sok esetben TIDM megjelenése nélkül. A 96 betegből 15 beteg esetében észleltek autoimmun thyreoiditist. A betegek közel 13\%-ában pozitív T1DM-asszociált autoantitestet igazoltak diabetes mellitus klinikai megjelenése nélkül (GAD, IAA, ICA), azonban ZNT8-autoantitest (zinc transporter 8 autoantibody) és IA-pozitivitás csak TIDM fennállása kapcsán igazolódott. Autoimmun thyreoiditis az IPEX-szindrómás betegek közel 16\%-ában jelentkezett.

\section{Endokrinológiai eltérések komplex immundeficientiában}

\section{Di George-szindróma}

A Di George által 1965-ben közölt 3 újszülött-kórleírásban thymus aplasia, immundefektus és parathyreoidea aplasia következtében fellépő neonatalis hypocalcaemia szerepel. A kórkép a későbbiekben a conotruncalis szívfejlődési rendellenességgel és a jellegzetes facialis dysmorphiával kiegészítve a Di George-szindróma megnevezést kapta. A Di George-szindróma klinikai képe nagyon változatos, közel 180-féle klinikai megjelenés ismert. A kórkép változatos megjelenése megnehezíti a kórkép felismerését, genetikai konzílium adását. A genetikai eltérést az esetek 90\%-ában a típusos 22q11.2-deletio adja, mely régió több mint 30 funkcionálógént tartalmaz. A legtöbb klinikai tünetért a deletálódó régióban elhelyezkedő $T B X 1$-gén (T-box-1-gén)-funkció kiesése felelős. A TBX1-gén által kódolt fehérje olyan transzkripciós faktor, mely szerepet játszik a parathyreoidea és a thyreoidea embrionális fejlődésében egyaránt.

Azonban a hypoparathyreosis kialakulásának patomechanizmusa pontosan nem ismert. A TBXI transzkripciós faktor funkciójának hiánya következtében kialakuló congenitalis mellékpajzsmirigy-hypoplasia mellett a mellékpajzsmirigy-elégtelenség folyamatában szerepet játszik a thymushypoplasia következtében kialakuló autoimmunitás folyamata is. Di George-szindrómában a kalciumszenzor-receptor ellen termelődő blokkoló és stimuláló autoantitestek megjelenése is ismert. A bete- gek közel harmadában a pajzsmirigyellenes autoantitestek megjelenése is igazolható [31].

A hypocalcaemia újszülöttkorban jelentkezik a leggyakrabban, általában görcs formájában. Jellemző laboratóriumi eltérések a hypocalcaemiás állapotban meghatározott alacsony vagy normál szérumparathormonszint. A Monteiro és mtsai által összeállított szakmai ajánlás szerint a neonatalis hypocalcaemia idiopathiás hypoparathyreosissal a 22q11.2-deletio, a Di Georgeszindróma genetikai vizsgálatának abszolút indikációja [32].

Az esetek jelentős részében a hypocalcaemia átmeneti, de az életkor előrehaladtával a mellékpajzsmirigy szekréciós kapacitásának csökkenése például stresszhelyzetben vagy infekció kapcsán ismét hypocalcaemiás tünetek megjelenését okozhatja. Felnőttkorban tetania vagy görcs fellépése ritkább, de Di George-szindrómában a hypocalcaemia bármelyik életkorban jelentkezhet. Permanens hypoparathyreosis fennállása is ismert.

Lima és mtsai országos vizsgálat keretében 59, Di George-szindrómás beteg adatait elemezték [33]. A betegek 47\%-ában fordult elő tranziens vagy permanens hypocalcaemia, 25\%-ban az újszülöttkorban. A betegek 10\%-ában találtak autoimmun megbetegedést. CYP450c21, CYP450c17, CYP450scc mellékvesekéregellenes autoantitestek és anti-TPO és anti-Tg pajzsmirigy-autoantitest megjelenését igazolták normál mellékvesekéreg- és pajzsmirigyfunkció mellett.

\section{Ataxia teleangiectasia}

Az ataxia teleangiectasiában szenvedő gyermekek szomatikus fejlődése a kortársaikéhoz képest elmaradott. A növekedési hormon-IGFl-tengely funkciójának megítélése azonban ellentmondásos. Normális növekedésihormon-szekréció alátámasztására és súlyos növekedésihormon-hiány fennállására is van irodalmi adat. A változó mértékű gonadfunkció-elégtelenség a betegek jelentős részében ismert jelenség. Nissenkorn és mtsai országos vizsgálatuk során 52 beteg adatait elemezték [34]. Megfigyelésük szerint csecsemőkorban a betegek testmagassága szubnormális volt, 4 éves korig a testmagasságelmaradottság a testsúly-elmaradottsághoz képest kifejezettebb volt. Ezt követően a testsúlyeltérés vált kifejezővé. Az átlagos szérum-IGFl- (insulin-like growth factor 1) szint alacsony volt. Az eredmények alapján a szerzők feltételezik, hogy a növekedési elmaradottság az ataxia teleangiectasiát okozó génmutáció és nem a betegség okozta szomatikus fejlődési zavar következménye. Nők esetében már 10 éves kortól magas FSH-, LHszinttel járó gonadfunkció-zavar manifesztálódott, a pubertás zavara, amenorrhoea, anovulációs ciklusok, infertilitás képében. Férfiak esetében azonban a kórképre jellemző meiosiszavar csak a spermatogenesist érintette, infertilitást idézve elő (magas FSH-szint, normál LH- és tesztoszteronszint). Inzulinrezisztencia és metforminke- 
zeléssel jól egyensúlyban tartható T2DM előfordult. A betegek háromnegyed részében $\mathrm{D}$-hipovitaminózis igazolódott.

\section{Megbeszélés}

A rendelkezésre álló adatok primer immundeficientiában az endokrinológiai diszfunkciók gyakoriságának fokozódását igazolják. Ebben az autoimmun folyamatok prevalenciájának megnövekedése mellett az egyes kórképekben megnyilvánuló endokrinológiai diszfunkciókat elemző tanulmányok megszaporodott száma is szerepet játszik. Az adatok a primer immundeficientia asszociálta hormonális eltérések vonatkozásában is jelentős populációs és földrajzi különbséget mutatnak. Példa erre az APECED-szindrómában előforduló primer hypadrenia eltérő megjelenési gyakorisága a finn és a japán populációban vagy a pajzsmirigy-érintettség előfordulásának különbözősége Európában és Amerikában. Az adatok igazolják, hogy a primer immundeficientiához társuló endokrinológiai diszfunkciók patomechanizmusában döntő szerepe van az autoimmun folyamatnak, az egyes

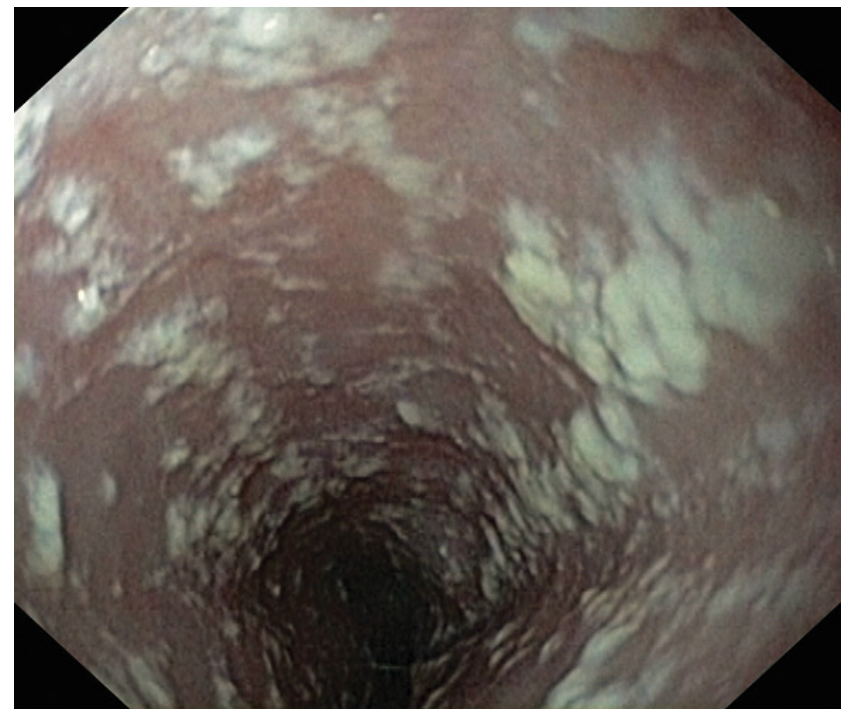

1. ábra

Az APECED-szindrómás beteg 19 éves korában végzett felső endoszkópiás vizsgálata során a nyelőcső teljes hosszában látha tó a szövettanilag igazolt gyulladás és mycoticus elváltozás

APECED = autoimmun polyendocrinopathia, candidiasis, ectodermalis dystrophia
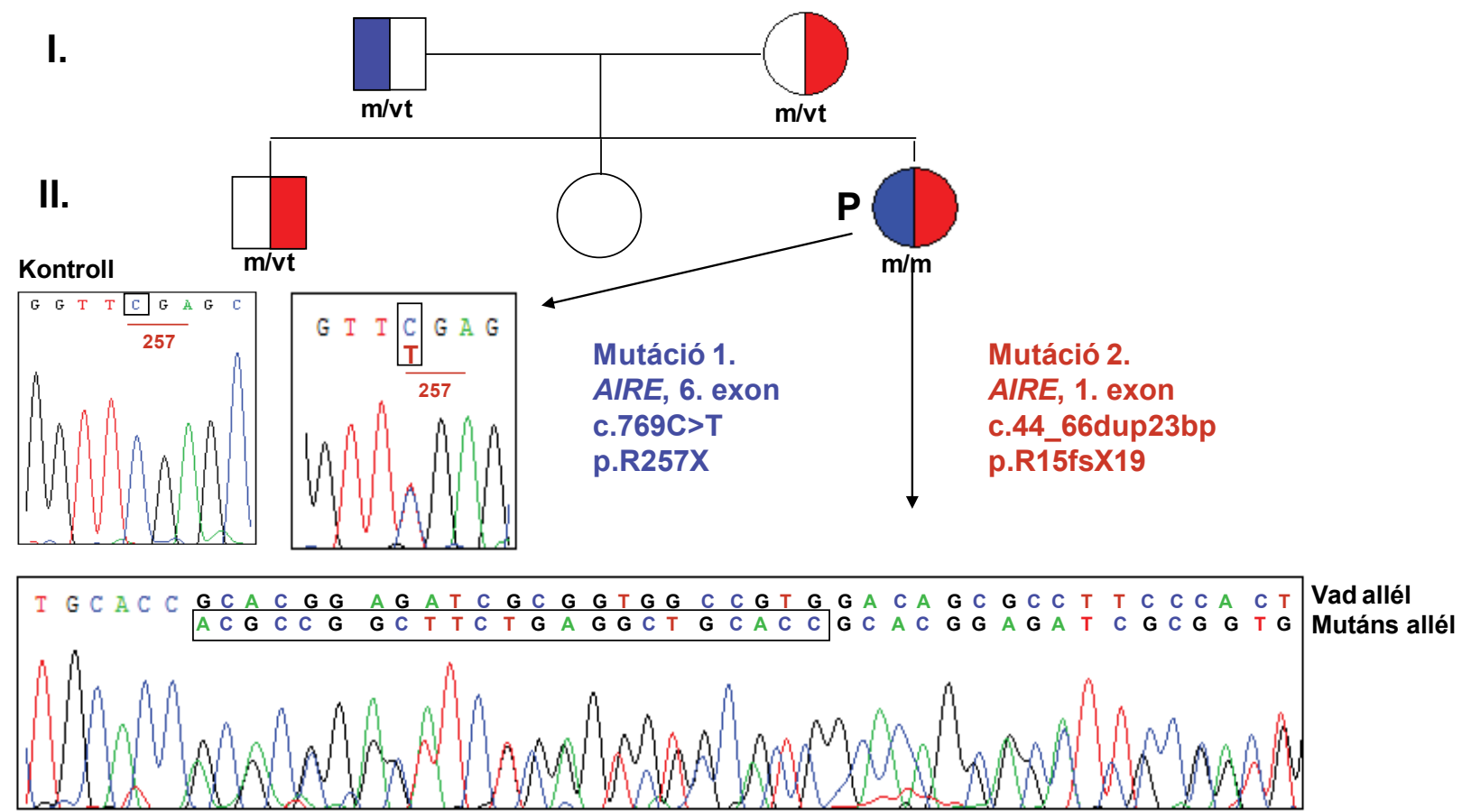

Kontroll

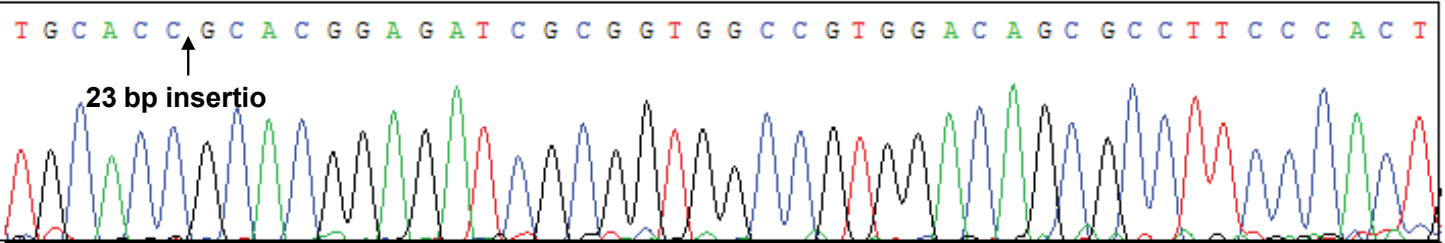

2. ábra

Az AIRE-gén molekuláris genetikai vizsgálatának eredménye az APECED-szindrómában szenvedő betegben, szüleinél és testvéreinél

A proband compound heterozigóta, szülei és fiútestvére hordozó, leánytestvére betegségokozó mutációt nem hordoz (m: mutáns allél, vt: vad típusú allél)

(A genetikai vizsgálat elvégzésére a DE KK Infektológiai és Gyermekimmunológiai Tanszék Genetikai Laboratóriumában került sor 
endokrin szervek ellen termelődő szervspecifikus autoantitestek képződésének. A legtöbb, de nem minden esetben az autoantitest megjelenése az endokrin szervek múködésének zavarát előre jelzi és előidézi. Típusos esetben az APECED-, az IPEX- és a Di George-szindrómában az endokrin rendszer diszfunkciója már gyermekkorban manifesztálódik. A kórképekben azonban a hormonrendszer eltéréseit a manifesztáció időpontjának, az elváltozás súlyosságának vonatkozásában is a klinikai heterogenitás jellemzi. Az immundeficientiához társuló endokrinológiai eltérések ismerete segítséget nyújt a diagnózis felállításához, és felhívja a figyelmet a beteg gondozása során szükséges szúrővizsgálatok szerepére, az endokrinológiai gondozás szükségességére.

\section{Esetismertetés}

A 7 éves leány felvételére sürgősséggel, prekomatózus állapotban került sor. Anamnézisében szövődménymentes appendectomia szerepelt. A felvételét megelőző hónapokban visszatérô sorozatos hányás miatt hospitalizálásra került sor. Állapota infúziós kezelést követően minden esetben rövid időn belül rendeződött, így kórházi kezelése csak néhány napra szorítkozott. A panaszait pszichés megterheléssel magyarázták (nagymama halála). Klinikai felvételekor az elesett gyermeknél jelentős hyponatraemiát és hyperkalaemiát észleltünk, hypoglykaemia, metabolikus acidosis kíséretében (se-Na: 108 $\mathrm{mmol} / \mathrm{l}$, se-K: 5,6 mmol/l). Az endokrinológiai vizsgálatok a kórkép hátterében primer mellékvesekéreg-elégtelenséget igazoltak, autoimmun etiológiával (se-kortizol: $<2,5 \mu \mathrm{g} / \mathrm{dl}$, se-aldoszteron: 0,4 ng/dl, PRA: 17,4 $\mathrm{ng} / \mathrm{ml} / \mathrm{h}$, pl-ACTH: $>1500 \mathrm{pg} / \mathrm{ml}$, mellékvesekéregellenes antitest: pozitív, P450cl7 pozitív; P450scc pozitív, P450c2l negatív). Glüko- és mineralokortikoidkezelés bevezetésével állapota rövid időn belül rendeződött. Öt hónappal később a kontrollvizsgálaton ujjai és a kézfejek zsibbadásáról számolt be, a laboratóriumi vizsgálatok hypoparathyreosis fennállását jelezték (se-Ca: 1,3 $\mathrm{mmol} / \mathrm{l}$, se-P: $3,37 \mathrm{mmol} / \mathrm{l}$, se intakt parathormon: 0,1 pmol/1). Terápiája ekkor kalcium, magnézium és D-vitamin adásával egészült ki. A leánynál az autoimmun adrenalitis és hypoparathyreosis diagnózisa az APECEDszindróma fennállását igazolta. Gyermekendokrinológiai további gondozása kapcsán a kórképhez terápiára rosszul reagáló gingivitis, rekurráló szájüregi mycosis, autoimmun thyreoiditis és váltakozó jelleggel alopecia társult. Felnőttgondozásba 19 évesen került át, ekkor nyelési és hasi panaszai hátterében kiterjedt mycoticus oesophagitis és gastritis állt (1. ábra). A családban elvégzett molekuláris genetikai vizsgálat eredményét a 2. ábra mutatja be. A leánynál az AIRE-gén molekuláris genetikai vizsgálata compound (összetett) heterozigótamutáció fennállását igazolta (c.769C>T/c.44_66dup23bp, mely R257X/R15fsX19-aminosav-cserét okozott). Haplotípus: D21S1912:4, PFKl:3. A családvizsgálat kapcsán az édesapánál és a fiútestvérnél a c.769C/T-mutáció, az édesanyánál a c.44_66dup23bp-mutáció-hordozás igazolódott heterozigóta formájában, a leánytestvér az $A I R E$-gén betegségokozó mutációját nem hordozta $[35,36]$.

$\mathrm{Az}$ ismertetett klinikai esetben az APECED-szindróma kezdeti klinikai manifesztációja a diagnosztikus triász két, endokrinológiai szerveket érintő autoimmun megbetegedése volt, ami az APECED-szindróma dignózisának felállítását megkönnyítette. Az évek során a mellékvesekéreg és a mellékpajzsmirigy autoimmun megbetegedéséhez számos nem endokrin szerv érintettsége társult. A genetikai vizsgálat további családtag érintettségét nem igazolta.

Anyagi támogatás: A kézirat megírása, illetve a kapcsolódó kutatómunka anyagi támogatásban nem részesült.

A szerző a cikk végleges változatát elolvasta és jóváhagyta.

Érdekeltségek: A szerzőnek nincs érdekeltsége.

\section{Irodalom}

[1] Kanczkowski W, Alexaki VI, Tran N, et al. Hypothalamo-pituitary and immune-dependent adrenal regulation during systemic inflammation. Proc Natl Acad Sci USA 2013; 110: 1480114806.

[2] Nordlind K, Sundström E. Different modulating effects of the monoamines adrenaline, noradrenaline, and serotonin on the DNA synthesis response of human peripheral blood T lymphocytes activated by mercuric chloride and nickel sulfate. Int Arch Allergy Appl Immunol. 1988; 87: 317-320.

[3] Balázs Cs, Fehér J. Associations of autoimmune disorders in endocrine diseases. [Autoimmun endokrin kórképek társulásai.] Orv Hetil. 2009; 150: 1589-1597. [Hungarian]

[4] Csaba Gy. The immuno-endocrine system. A new endocrine theory: the problem of the packed transport. [Az immun-endokrin rendszer. Egy új endokrin elmélet: a sejtes szállítmányozás problémája.] Orv Hetil. 2011; 152: 777-784. [Hungarian]

[5] Arason GJ, Jorgensen GH, Ludviksson BR. Primary immunodeficiency and autoimmunity: lessons from human diseases. Scand J Immunol. 2010; 71: 317-328.

[6] Moraes-Vasconcelos D, Costa-Carvalho BT, Torgerson TR, et al. Primary immune deficiency disorders presenting as autoimmune diseases: IPEX and APECED. J Clin Immunol. 2008; 28(Suppl 1): S11-S19.

[7] Nozaki T, Takada H, Ishimura M, et al. Endocrine complications in primary immunodeficiency diseases in Japan. Clin Endocrinol. 2012; 77: 628-634.

[8] Takada H. Primary immunodeficiency in Japan; epidemiology, diagnosis, and pathogenesis. Pediatr Int. 2013; 55: 671-674.

[9] Oftedal BE, Hellesen A, Erichsen MM, et al. Dominant mutations in the autoimmune regulator AIRE are associated with common organ-specific autoimmune disease. Immunity 2015; 42: 1185-1196.

[10] Maródi L. Inborn errors of T cell immunity underlying autoimmune diseases. Expert Rev Clin Immunol. 2017; 13: 97-99.

[11] Perheentupa J. Autoimmune polyendocrinopathy-candidiasisectodermal dystrophy. J Clin Endocrinol Metab. 2006; 91: 2843-2850.

[12] Neufeld M, Maclaren NK, Blizzard RM. Two types of autoimmune Addison's disease associated with different polyglandular 
autoimmune (PGA) syndromes. Medicines (Baltimore) 1981; 60: 355-362.

[13] Ahonen P, Myllärniemi S, Sipilä I, et al. Clinical variation of autoimmune polyendocrinopathy-candidiasis-ectodermal dystrophy (APECED) in a series of 68 patients. N Engl J Med. 1990; 322: 1829-1836.

[14] Betterle C, Greggio NA, Volpato M. Clinical review 93: Autoimmune polyglandular syndrome type 1. J Clin Endocrinol Metab. 1998; 83: 1049-1055.

[15] Ferre EM, Rose SR, Rosenzweig SD, et al. Redefined clinical features and diagnostic criteria in autoimmune polyendocrinopathy-candidiasis-ectodermal dystrophy. JCI Insight 2016; 1: e88782.

[16] Kahaly GJ. Polyglandular autoimmune syndromes. Eur J Endocrinol. 2009; 161: 11-20.

[17] Proekt I, Miller CN, Lionakis MS, et al. Insights into immune tolerance from AIRE deficiency. Curr Opin Immunol. 2017; 49: 71-78.

[18] Balázs Cs. Associations of autoimmune endocrine diseases. In: Leövey A, Nagy VE, Paragh Gy, et al. (eds.) Practical textbook of endocrine and metabolic disorders. [Autoimmun poliendokrin kórképek és társulásai (APS). In: Leövey A, Nagy VE, Paragh Gy, et al. (szerk.) Az endokrin és anyagcsere-betegségek gyakorlati kézikönyve.] Medicina Könyvkiadó, Budapest, 2017; pp. 479491. [Hungarian]

[19] Wolff AS, Sarkadi AK, Maródi L, et al. Anti-cytokine autoantibodies preceding onset of autoimmune polyendocrine syndrome type I features in early childhood. J Clin Immunol. 2013; 33: 1341-1348.

[20] Puel A, Döffinger R, Natividad A, et al. Autoantibodies against IL-17A, IL-17F, and IL-22 in patients with chronic mucocutaneous candidiasis and autoimmune polyendocrine syndrome type I. J Exp Med. 2010; 207: 291-297.

[21] Kemp EH, Habibullah M, Kluger N, et al. Prevalence and clinical associations of calcium-sensing receptor and NALP5 autoantibodies in Finnish APECED patients. J Clin Endocrinol Metab. 2014; 99: 1064-1071.

[22] Kashem SW, Binstadt BA. Pathogenic and protective autoantibodies in autoimmune polyendocrinopathy-candidiasis-ectodermal dystrophy (APECED). Antibodies 2017; 6: 1 .

[23] Orlova EM, Sozaeva LS, Kareva MA, et al. Expanding the phenotypic and genotypic landscape of autoimmune polyendocrine syndrome type 1. J Clin Endocrinol Metab. 2017; 102: 35463556.

[24] Eriksson D, Dalin F, Eriksson GN, et al. Cytokine autoantibody screening in the Swedish Addison Registry identifies patients with undiagnosed APS1. J Clin Endocrinol Metab. 2018; 103: 179-186.
[25] Huopio H, Miettinen PJ, Ilonen J, et al. Clinical, genetic, and biochemical characteristics of early-onset diabetes in the Finnish population. J Clin Endocrinol Metab. 2016; 101: 3018-3026.

[26] Fierabracci A. Type 1 diabetes in autoimmune polyendocrinopathy-candidiasis-ectodermal dystrophy syndrome (APECED): a 'rare' manifestation in a 'rare' disease. Int J Mol Sci. 2016; 17: 1106.

[27] Bensing S, Fetissov SO, Mulder J, et al. Pituitary autoantibodies in autoimmune polyendocrine syndrome type 1 . Proc Natl Acad Sci USA 2007; 104: 949-954.

[28] Rubio-Cabezas O, Minton JA, Caswell R, et al. Clinical heterogeneity in patients with FOXP3 mutations presenting with permanent neonatal diabetes. Diabetes Care 2009; 32: 111-116.

[29] Barzaghi F, Passerini L, Bacchetta R. Immune dysregulation, polyendocrinopathy, enteropathy, $\mathrm{X}$-linked syndrome: a paradigm of immunodeficiency with autoimmunity. Front Immunol. 2012; 31: 1-25.

[30] Barzaghi F, Amaya Hernandez LC, Neven B, et al. Long-term follow-up of IPEX syndrome patients after different therapeutic strategies: an international multicenter retrospective study. J. Allergy Clin Immunol. 2018; 141: 1036-1049.e5. [Epub 2017 Dec 11]

[31] Mantovani G, Elli FM, Corbetta S. Hypothyroidism associated with parathyroid disorders. Best Pract Res Clin Endocrinol Metab. 2017; 31: 161-173.

[32] Monteiro FP, Vieira TP, Sgardioli IC, et al. Defining new guidelines for screening the $22 \mathrm{q} 11.2$ deletion based on a clinical and dysmorphologic evaluation of 194 individuals and review of the literature. Eur J Pediatr. 2013; 172: 927-945.

[33] Lima K, Abrahamsen TG, Wolff AB, et al. Hypoparathyroidism and autoimmunity in the $22 \mathrm{q} 11.2$ deletion syndrome. Eur J Endocrinol. 2011; 165: 345-352.

[34] Nissenkorn A, Levy-Shraga Y, Banet-Levi Y, et al. Endocrine abnormalities in ataxia telangiectasia: findings from a national $\mathrm{co}^{-}$ hort. Pediatr Res. 2016; 79: 889-894.

[35] Cihakova D, Trebusak K, Heino M, et al. Novel AIRE mutations and P450 cytochrome autoantibodies in Central and Eastern European patients with APECED. Hum Mutat. 2001; 18: 225232.

[36] Tóth B, Wolff AS, Halász Z, et al. Novel sequence variation of $A I R E$ and detection of interferon- $\omega$ antibodies in early infancy. Clin Endocrinol (Oxf). 2010; 72: 641-647.

(Halász Zita dr., Budapest, Bókay J. u. 53., 1083 e-mail: halaszzita@med.semmelweis-univ.hu) 